\title{
Bird Displacement by Wind Turbines: Assessing Current Knowledge and Recommendations for Future Studies
}

\author{
Ana Teresa Marques ${ }^{1,2,3, * \mathbb{D}}$, Helena Batalha ${ }^{4}$ and Joana Bernardino ${ }^{1,2,3} \mathbb{D}$ \\ 1 CIBIO, Centro de Investigação em Biodiversidade e Recursos Genéticos, InBIO Laboratório Associado, \\ Campus de Vairão, Universidade do Porto, 4485-661 Vairão, Portugal; jbernardino@cibio.up.pt \\ 2 CIBIO, Centro de Investigação em Biodiversidade e Recursos Genéticos, InBIO Laboratório Associado, \\ Instituto Superior de Agronomia, Universidade de Lisboa, 1349-017 Lisboa, Portugal \\ 3 BIOPOLIS Program in Genomics, Biodiversity and Land Planning, CIBIO, Campus de Vairão, \\ 4485-661 Vairão, Portugal \\ 4 School of Biological Sciences, University of East Anglia, Norwich NR47TJ, UK; h.batalha@uea.ac.uk \\ * Correspondence: anateresamarques@cibio.up.pt; Tel.: +351-252-660-400
}

check for updates

Citation: Marques, A.T.; Batalha, H.; Bernardino, J. Bird Displacement by Wind Turbines: Assessing Current Knowledge and Recommendations for Future Studies. Birds 2021, 2, 460-475. https://doi.org/10.3390/ birds2040034

Academic Editor: Jukka Jokimäki

Received: 6 November 2021

Accepted: 7 December 2021

Published: 10 December 2021

Publisher's Note: MDPI stays neutral with regard to jurisdictional claims in published maps and institutional affiliations.

Copyright: (c) 2021 by the authors. Licensee MDPI, Basel, Switzerland. This article is an open access article distributed under the terms and conditions of the Creative Commons Attribution (CC BY) license (https:/ / creativecommons.org/licenses/by/ $4.0 /)$.
Simple Summary: Wind turbines can affect bird populations by causing mortality when birds collide with turbine blades or displacement when the individuals move permanently to other areas. While mortality is well documented, displacement has only been studied more extensively in the last decade, and it is important to summarise the current knowledge and research trends. We reviewed 71 peer-reviewed studies on displacement and compiled: (1) information on the geographical areas, type of wind farm, study design and bird groups studied; and (2) the evidence of displacement effects on different bird groups. We found that most studies have been conducted in Europe and North America, particularly in agricultural areas. About half of the studies did not find any effects, for wind farms both on land and at sea, while many studies (40.6\%) found displacement effects, and a small proportion $(7.7 \%)$ detected attraction, i.e., an increased abundance of birds around the wind farms. For future studies, we recommend a robust and standardised study design, and highlight the importance of reporting and disseminating results, whether effects are positive, negative or absent.

Abstract: Wind energy developments can be responsible for negative impacts on birds, including displacement. In this study we performed a systematic review of the literature available on bird displacement due to wind turbines, both onshore and offshore, to: (i) assess overall trends in scientific research; (ii) review the existing knowledge; and (iii) outline recommendations for future studies on this topic in order to overcome the major gaps and limitations found. Our results are based on 286 trials extracted from 71 peer-reviewed studies. The literature on this topic has increased in the past decade but is concentrated in Europe and United States, despite the fact that the wind industry has worldwide coverage. Open habitats-as agricultural fields and grasslands-were the most represented and Accipitriformes, Galliformes, Charadriiformes, Anseriformes and Passeriformes were the most frequently studied taxa. Displacement was recorded in $40.6 \%$ of the trials, and Gaviiformes, Anseriformes, Suliformes, Accipitriformes and Falconiformes were the most affected groups. Pelecaniformes, Passeriformes and Charadriiformes were the groups for which no significant effects were more often observed. We provide a list of recommendations, focused on study design, reporting and result dissemination, that should contribute to more robust conclusions of future studies on this topic.

Keywords: energy; wind farms; space use; indirect effects; offshore; onshore; impact assessment; avoidance; study design

\section{Introduction}

The exponential expansion of wind energy production in recent decades, driven by decarbonization goals and financial incentives by some governments, has promoted multi- 
ple interactions between human activities and ecological systems [1]. Mortality is probably the most well-documented effect on wildlife, occurring when flying birds and bats collide with wind turbines [2-4]. Additionally, when placed in natural or seminatural habitats, infrastructures associated with the wind industry modify the landscape, promoting habitat loss and fragmentation, and may alter species behaviour [3,5], potentially leading to multiple ecological impacts [6,7], and ultimately population-level effects.

Besides habitat alterations associated with wind farms, the visual intrusion caused by the turbines, the rotating blades, noise and vibration resulting from turbine operation, and human or vehicle circulation due to the construction or maintenance activities, may cause disturbance to birds, during both the construction and operational phases [3]. Such activities may trigger an avoidance response that can occur at three spatial scales: macroavoidance when birds avoid the wind-power plant area as a whole, meso-avoidance if turbine arrays or single turbines are avoided, and micro-avoidance, which consists in last-second evasive movements of the rotor blades [5]. Depending on the study design and wind farm layout (with clustered/random turbines) it may not be possible to fully disentangle macro and meso-avoidance.

Here, we consider displacement as the reduced density of birds occurring near wind turbines, due to long-term disturbance leading to functional habitat loss, i.e., the joint effect of macro-avoidance and meso-avoidance [5]. Conversely, we define attraction as an increase in bird density within or near the wind farm. Attraction has been described mostly in the offshore industry, as infrastructures associated with wind energy production may provide favourable roosting conditions or act as a reef, increasing food resources [8]. However, an attraction effect is not necessarily positive for birds, as it increases their risk of collision with turbines.

Previous reviews already gathered valuable knowledge on bird displacement; however, these studies were performed more than 15 years ago $[9,10]$ or focused on specific taxa [11-13], habitats [14,15], and on offshore [8,16] or onshore developments [17,18].

In this systematic review, we aim to provide a global assessment of current knowledge on bird displacement due to wind turbines, both onshore and offshore. The specific aims of this study are three-fold: (i) assess overall trends in scientific research and identify knowledge gaps, in terms of geographic areas, taxa and habitats; (ii) review the existing knowledge about displacement or attraction effects per taxa; and (iii) provide recommendations for future studies on this topic.

\section{Materials and Methods}

To assess research trends and current knowledge on bird displacement due to wind farms operation, we performed a systematic review of the peer-reviewed literature on the topic, found through two complementary search strategies. First, we performed a webbased search in the ISI Web of Knowledge and Scopus databases. Searches were performed in July 2021, using the keywords "bird" and "wind" combined with the following terms: "attraction", "displacement", "disturbance", "habitat loss" and "habitat selection". Second, we screened the reference list of previous reviews on the indirect effects of wind farms and complemented the list of studies with references from our personal bibliography.

For our analysis, we only considered articles containing original and empirical data (i.e., data from review papers or assessments of potential effects of future developments were not included) and restricted the screening to peer-reviewed studies, due to quality control issues. We included all the works focusing on: bird abundance or density, space use (intensity), probability of occurrence (presence/absence), indirect signs density (e.g., droppings), and nest site selection/density. The steps followed for the identification, screening and inclusion of studies are represented in a PRISMA flow diagram [19] in Appendix A.

Each study was characterized according to the type of wind farm (offshore or onshore), country/geographic region, sampling design (BACI before-after control-impact; BAG before-after-gradient; BAG-C before-after-gradient, with a control; IG impact-gradient; 
IG-C impact-gradient, with a control; BA before-after and CI control-impact) [20], target groups following the IOC World Bird List [21], habitat, phenological season, methods or technology used for data collection and the number of years since the beginning of operation. Phenological season was classified as breeding, post-breeding, winter and migration, according to the categorization established by the original study.

Regarding the evidence of bird displacement by wind turbines, we categorized the effects (variations in the parameter of interest) reported by the original study as: negative (displacement), positive (attraction), no effect (without significant variation) or inconclusive (when the authors acknowledge that the results may be influenced by confounding factors, like differences in habitats or other sources of disturbance). Whenever available, we also extracted information on maximum distance with an effect (in meters) and relative variation $(\%)$ in abundance, density or space use. When a study reported independent results for multiple combinations of factors (e.g., target species or groups, years, seasons, areas), we considered those as separate trials.

\section{Major Trends in Research}

We found a total of 71 studies focusing on the effects of wind turbines on bird space use or abundance. The first studies go back to the 1990s, and this research topic became consistently more frequent after 2010. The majority of studies focused on onshore wind farms $(n=56 ; 79 \%)$ when compared with offshore power plants $(n=15 ; 21 \%)$ (Figure 1$)$, probably reflecting the large proportion of the onshore industry [22]. The study area characteristics could be quite variable, as some studies focus on single wind farms, whilst others focus on multiple ones (maximum of 27), ranging from 1 to over 9000 wind turbines studied.

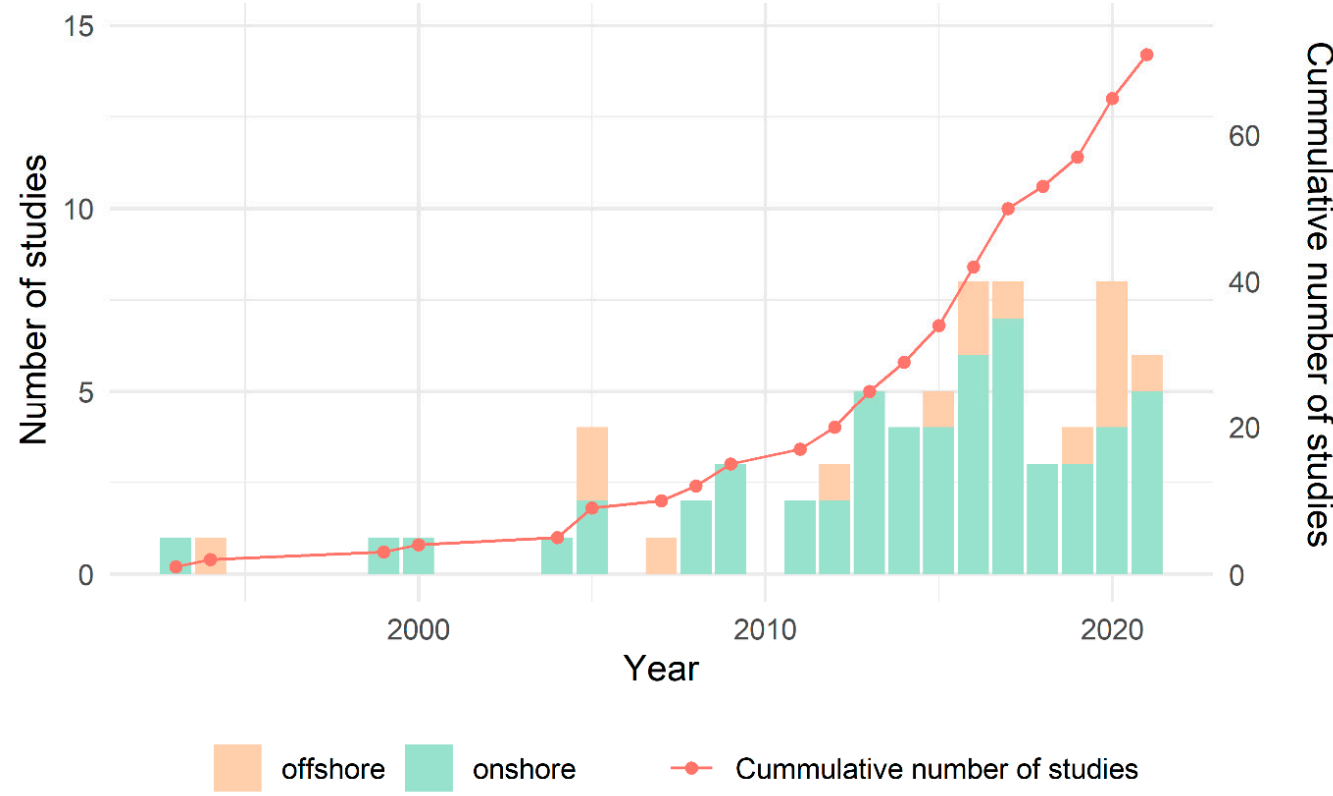

Figure 1. Number of studies per publication year focusing on bird displacement by wind turbines, for offshore and onshore wind farms. Data for 2021 are incomplete, as the bibliographic research was conducted in July 2021.

Despite wind energy production already being fairly present around the globe, the large majority of research on this topic is concentrated in Europe (65\%) and the United States (28\%) (Figure 2), probably due to the environmental legislation in these regions, namely the Environmental Impact Assessment (EIA) Directive and Nature legislation in the European Union, and the National Environmental Policy Act (NEPA) in the United States [23]. Studies from wind farms in Asia started being published in 2020, suggesting that data from new regions may be arising. We found no studies focusing on displacement effects in Africa or South America. 

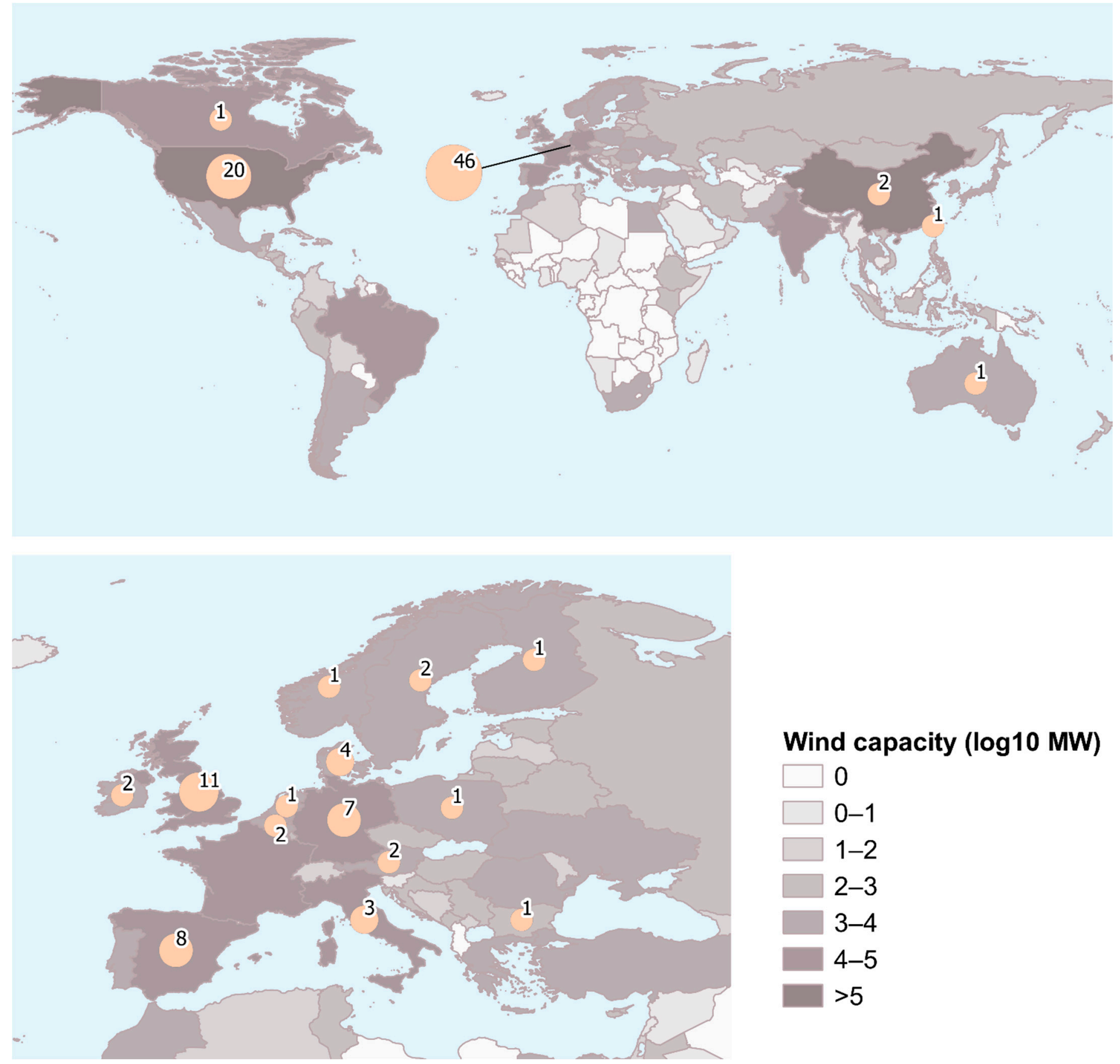

Figure 2. Wind energy installed capacity $(\log 10 \mathrm{MW})$ [22] and distribution of original studies on bird displacement by wind turbines reviewed in this study $(n=71)$ at global (top) and European (bottom) scales.

Most studies were conducted during the breeding season (54\%) and focused mainly on open landscapes as agricultural fields (30\%) and grasslands (23\%) (Figure 3). At least 110 species were studied, with Accipitriformes (18\%), Galliformes (18\%), Charadriiformes $(17 \%)$, Anseriformes (14\%) and Passeriformes (13\%) being the most frequently studied groups. A wide variety of experimental sampling designs were used across the studies, with IG $(24 \%)$, BA (18\%) and CI (18\%) being the most common ones (Figure 3). Study designs that combined a before-after approach (temporal control of the measured parameters) with near/far or distance-to-turbine sampling (BACI, BAG and BAG-C), i.e., those with more powerful sampling designs, were only implemented in $28 \%$ of the studies. Traditional birds census techniques that use human observers to collect the field data (e.g., point counts, transects, vantage points) were implemented by the large majority of the authors (73\%); 
technology, such as GPS tracking devices $(20 \%)$ or radar technology $(6 \%)$ were also used. Finally, most of the studies (48\%) were conducted in the first four years after the beginning of the wind farm operation, and only a lower fraction (35\%) focused on medium/long-term effects ( $>5$ years after the beginning of operation; only $14.1 \%>10$ years).

\section{Bird groups}

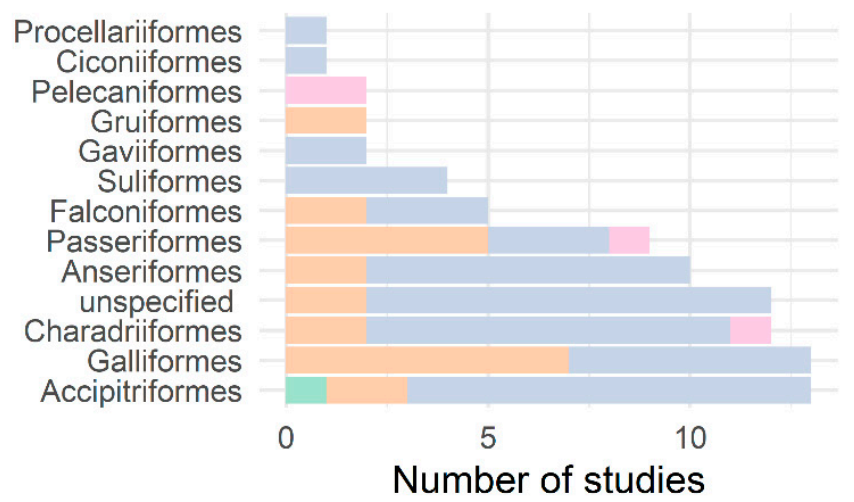

\section{Season}

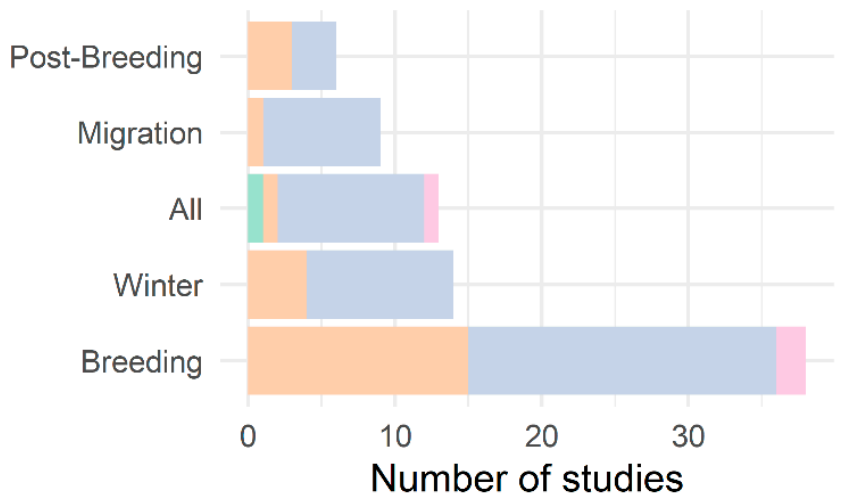

Asia

\section{Habitat}

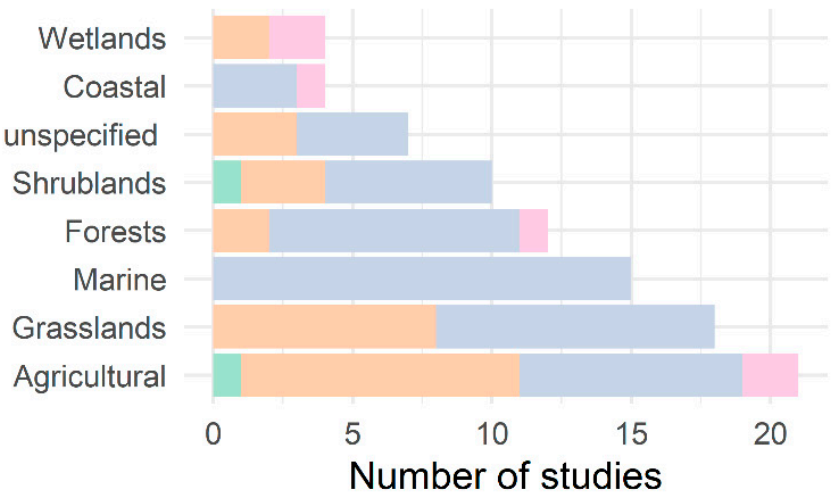

Study design

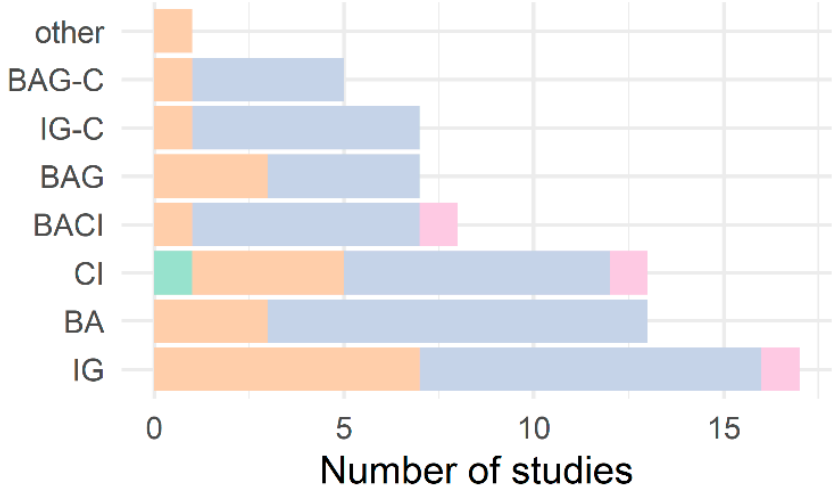

North America

Oceania

Figure 3. Number of studies distributed according to bird groups, habitat, phenological season and study design (BACI before-after-control-impact; BAG before-after-gradient; BAG-C before-after-gradient, with a control; IG impact-gradient; IGC impact-gradient, with a control; BA before-after and CI control-impact) reviewed in this study $(n=71)$ and discriminating between continents. Each study may be represented in more than one class (e.g., a study may focus on multiple bird groups and seasons).

\section{Current Knowledge on Bird Displacement by Wind Turbines}

We used the data from 68 of the 71 studies to assess the current knowledge on bird displacement, with a total of 286 trials. We excluded three studies from this analysis [24-26], whose information was duplicated, at least partially, in other works. We stress that, as the considered studies implemented quite variable methodological approaches (see previous section), comparisons across studies and taxa should be conducted with caution.

Overall, negative effects (i.e., displacement) were recorded in $40.6 \%$ of the trials, with offshore wind farms presenting a slightly higher frequency of displacement $(43.8 \%)$ when compared to onshore wind farms (39.3\%) (Figure 4). Still, attraction effects were recorded in $7.7 \%$ of the trials, being observed $15.0 \%$ at offshore wind farms, contrasting with only $4.9 \%$ at onshore environments (Figure 4 ). Such difference confirms previous findings that offshore wind farms may act as attractive locations for some species, by providing roosting locations and enhanced food resources as a result of an 'artificial reef effect' $[3,8]$. The lack 
of effects of wind turbines on birds' abundance and space use was reported in $49 \%$ of the trials (Figure 4).

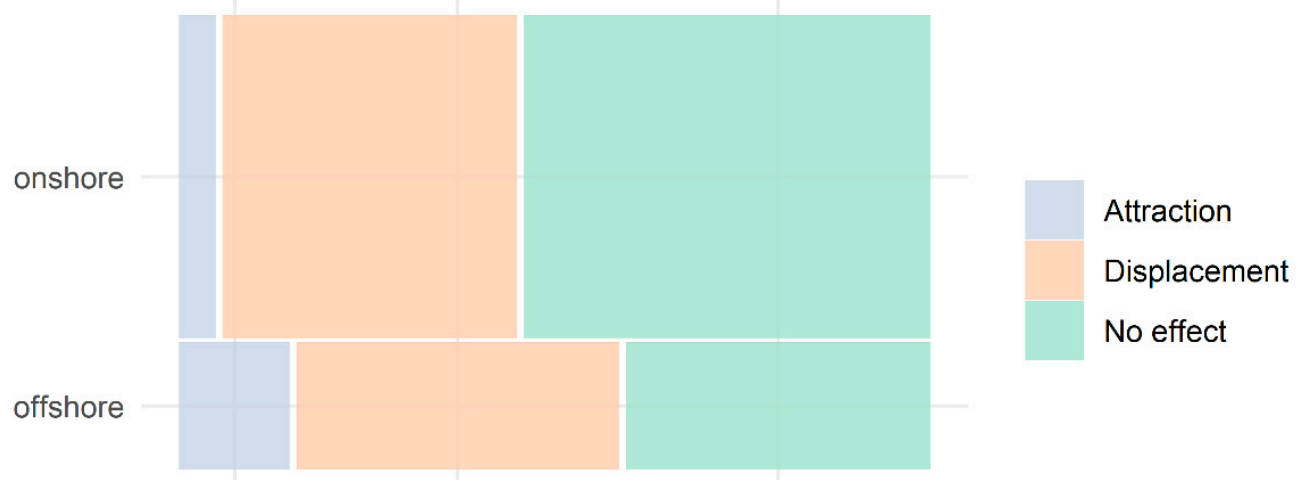

Figure 4. Relative frequency of trials $(n=286)$ reporting attraction, displacement or no effects of wind turbines on bird space use or abundance, per wind farm type. The bar width represents the number of experimental trials performed per wind farm type.

The large majority of the trials $(78.3 \%, n=224)$ used metrics of bird abundance or density to test the existence of effects ( 81 trials found evidence of displacement and 15 found attraction effects), followed by metrics of space use as utilization distribution $(11.2 \%, n=32$; 21 trials found displacement and 5 found attraction). Less used parameters include bird occupancy ( $4.2 \%, n=12 ; 5$ trials found displacement and no attraction was found), and indirect abundance metrics, as abundance of droppings and tracks $(3.5 \%, n=10 ; 8$ trials found displacement and 2 found attraction) or nest abundance $(2.8 \%, n=8 ; 1$ trial found displacement effect).

There is evidence of displacement, but also attraction, for the most studied groups. Displacement effects were reported for the majority of the trials involving Gaviiformes (100\%), Anseriformes (68.2\%), Suliformes (66.7\%), Accipitriformes (48.7\%) and Falconiformes (50.0\%). Although not prevalent, attraction effects were observed mostly in Falconiformes (12.5\%), Charadriiformes (11.6\%) and Accipitriformes (10.3\%); but never observed in Anseriformes, Gaviiformes, Pelecaniformes and Suliformes. On the other end, the lack of effects was prevalent in Pelecaniformes (75\%), Passeriformes (66.2\%) and Charadriiformes (55.1\%) (Figure 5, Table 1). Galliformes had a similar frequency of trials with evidence of displacement $(48.5 \%)$ and with the absence of effects $(45.5 \%)$. We highlight that Falconiformes, Gaviiformes and Pelecaniformes were studied in a low number of trials/studies, so their results should be considered preliminary.

The spatial extent of the effects of wind turbines on birds' space is highly variable across taxa and studies. Birds could be displaced from the turbines proximity up to mean distances ( \pm standard deviation) of $116 \pm 64 \mathrm{~m}$ in Anseriformes, $248 \pm 103 \mathrm{~m}$ in Passeriformes, $474 \pm 213 \mathrm{~m}$ in Accipitriformes, $2517 \pm 5560 \mathrm{~m}$ in Charadriiformes, $4557 \pm 4340 \mathrm{~m}$ in Galliformes, and 12,062 $\pm 6911 \mathrm{~m}$ in Gaviiformes (Table 1). Displacement effects also resulted in lower abundances near the wind energy facilities, with mean relative reductions of $40 \pm 24 \%$ in Passeriformes, $54 \pm 15 \%$ in Anseriformes, $56 \%$ in Galliformes, $59 \pm 18 \%$ in Charadriiformes, $59 \%$ in Falconiformes, $59 \pm 18 \%$ in Accipitriformes, $61 \pm 24 \%$ in Suliformes and $71 \pm 20 \%$ in Gaviiformes (Table 1). It is however important to note that, although the magnitude of the variations may seem relatively similar across taxa, the limits of the wind farm area, i.e., the area assumed to be under turbine influence and for which the variation was estimated, varied greatly across studies. 


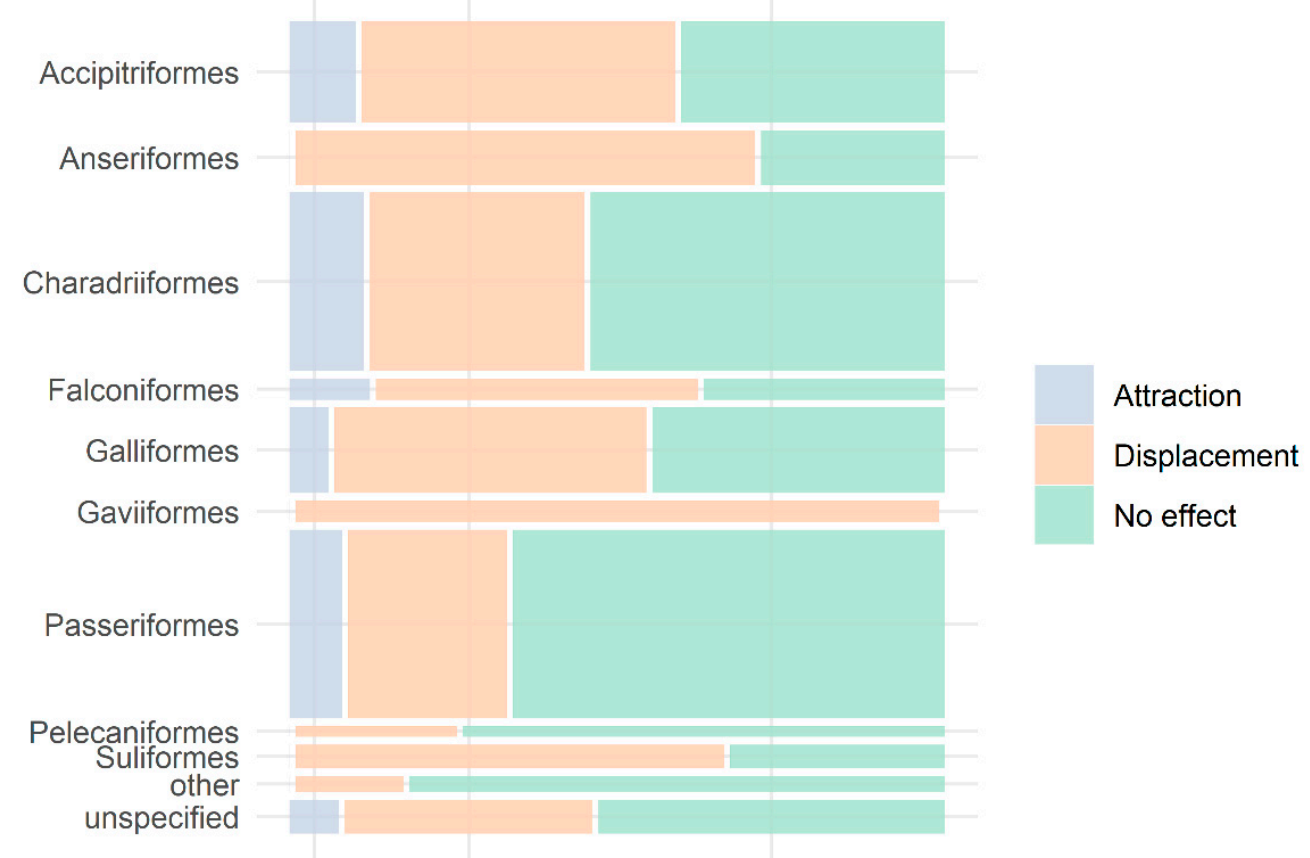

Figure 5. Relative frequency of trials $(n=286)$ reporting attraction, displacement or no effects of wind turbines on bird space use or abundance, per birds' group. The bar width represents the number of experimental trials performed per each birds' groups.

Table 1. Summary of the effects described per bird group in the 286 trials analysed in this review. Note that not all the studies reporting displacement or attraction effects provided the maximum distance or the relative variation of the effect. When there was data available for more than one study, mean values, standard deviation (SD) and range (minimum and maximum values) are presented.

\begin{tabular}{|c|c|c|c|c|c|}
\hline \multirow[b]{2}{*}{ Group } & \multirow[b]{2}{*}{ Effect } & \multirow[b]{2}{*}{$\begin{array}{c}\text { No. } \\
\text { Trials/No. } \\
\text { Studies }\end{array}$} & \multicolumn{2}{|c|}{ Wind Turbine Influence } & \multirow[b]{2}{*}{ Source } \\
\hline & & & $\begin{array}{l}\text { Maximum Distance } \\
\text { with Influence of } \\
\text { Wind Turbines (m) } \\
\text { Mean } \pm \text { SD (Range) }\end{array}$ & $\begin{array}{c}\text { Relative Variation in } \\
\text { Space Use or } \\
\text { Abundance }(\%) \\
\text { Mean } \pm \text { SD (Range) }\end{array}$ & \\
\hline \multirow{3}{*}{ Accipitriformes } & Attraction & $4 / 1$ & $\begin{array}{l}2125 \pm 250 \\
\text { (2000: } 2500)\end{array}$ & - & [27] \\
\hline & Displacement & $19 / 11$ & $474 \pm 213(250: 674)$ & $-59 \pm 18 \%(-40:-93)$ & [28-38] \\
\hline & No effect & $22 / 7$ & - & - & {$[28,29,33,34,39-41]$} \\
\hline \multirow{3}{*}{ Anseriformes } & Displacement & $15 / 6$ & $116 \pm 64$ (50: 200) & $-54 \pm 15 \%(-40:-75)$ & [42-47] \\
\hline & No effect & $6 / 3$ & - & - & {$[48-50]$} \\
\hline & Inconclusive & $1 / 1$ & - & - & [51] \\
\hline \multirow{3}{*}{ Charadriiformes } & Attraction & $8 / 4$ & 100 & $90 \pm 15 \%$ (79: 100) & {$[50,52-54]$} \\
\hline & Displacement & $23 / 9$ & $\begin{array}{l}2517 \pm 5560 \\
(100: 20,000)\end{array}$ & $-59 \pm 18 \%(-32:-92)$ & {$[31,52-59]$} \\
\hline & No effect & $38 / 12$ & - & - & {$[31,49,50,52-55,59-63]$} \\
\hline Ciconiiformes & No effect & $1 / 1$ & - & - & {$[41]$} \\
\hline Columbiformes & No effect & $2 / 2$ & & & {$[64,65]$} \\
\hline Cuculiformes & No effect & $2 / 2$ & & & {$[64,65]$} \\
\hline \multirow{3}{*}{ Falconiformes } & Attraction & $1 / 1$ & 2000 & - & [27] \\
\hline & Displacement & $4 / 3$ & - & $-59 \%$ & {$[28,33,34]$} \\
\hline & No effect & $3 / 3$ & - & - & {$[31,34,41]$} \\
\hline
\end{tabular}


Table 1. Cont.

\begin{tabular}{|c|c|c|c|c|c|}
\hline \multirow[b]{2}{*}{ Group } & \multirow[b]{2}{*}{ Effect } & \multirow[b]{2}{*}{$\begin{array}{c}\text { No. } \\
\text { Trials/No. } \\
\text { Studies }\end{array}$} & \multicolumn{2}{|c|}{ Wind Turbine Influence } & \multirow[b]{2}{*}{ Source } \\
\hline & & & $\begin{array}{l}\text { Maximum Distance } \\
\text { with Influence of } \\
\text { Wind Turbines (m) } \\
\text { Mean } \pm \text { SD (Range) }\end{array}$ & $\begin{array}{c}\text { Relative Variation in } \\
\text { Space Use or } \\
\text { Abundance (\%) } \\
\text { Mean } \pm \text { SD (Range) }\end{array}$ & \\
\hline \multirow{3}{*}{ Galliformes } & Attraction & $2 / 1$ & - & $475 \%$ & {$[66]$} \\
\hline & Displacement & $16 / 9$ & $\begin{array}{l}4557 \pm 4340 \\
(500: 10,500)\end{array}$ & $-56 \%$ & {$[17,67-74]$} \\
\hline & No effect & $15 / 12$ & ) & - & $\begin{array}{l}{[31,49,55,60,67-} \\
69,71,73,75-77]\end{array}$ \\
\hline Gaviiformes & Displacement & $8 / 4$ & $\begin{array}{l}12,062 \pm 6911 \\
(1750: 16,500)\end{array}$ & $-71 \pm 20 \%(-45:-90)$ & {$[49,52,78,79]$} \\
\hline \multirow{2}{*}{ Gruiformes } & Displacement & $1 / 1$ & 5000 & - & [80] \\
\hline & Inconclusive & $1 / 1$ & - & - & [81] \\
\hline \multirow{4}{*}{ Passeriformes } & Attraction & $6 / 4$ & $150 \pm 130(75: 300)$ & $7.4 \%$ & {$[30,53,55,71]$} \\
\hline & Displacement & $18 / 9$ & $248 \pm 103(80: 400)$ & $-40 \pm 24 \%(-15:-62)$ & {$[30,31,41,53,82-86]$} \\
\hline & No effect & $49 / 12$ & - & - & $\begin{array}{c}{[31,41,49,53,55,64,65,} \\
\quad 71,82,83,87,88]\end{array}$ \\
\hline & Inconclusive & $1 / 1$ & - & - & {$[87]$} \\
\hline \multirow{2}{*}{ Pelecaniformes } & Displacement & $1 / 1$ & - & - & {$[63]$} \\
\hline & No effect & $3 / 2$ & - & - & {$[63,89]$} \\
\hline \multirow{2}{*}{ Suliformes } & Displacement & $6 / 4$ & - & $-61 \pm 24 \%(-29:-85)$ & {$[50,52,54,90]$} \\
\hline & No effect & $1 / 1$ & - & - & [50] \\
\hline \multirow{3}{*}{ unspecified } & Attraction & $1 / 1$ & - & - & [91] \\
\hline & Displacement & $5 / 3$ & 100 & $-50 \%$ & [91-93] \\
\hline & No effect & $7 / 3$ & - & - & {$[54,71,92]$} \\
\hline
\end{tabular}

\section{Guidance and Opportunities for Future Studies}

Over the years, we have observed not only an increase in the number of studies conducted on the topic but also an improvement in the quality and utility of the results achieved. This progress is, nonetheless, not transversal to all studies and there are still opportunities for improvement in study design, reporting and result dissemination.

\subsection{Study Design}

Study design and systematic data collection are key elements in the monitoring of anthropogenic impacts [94]. Poorly designed experiments typically lead to inaccurate or inconclusive results, as evaluating displacement and other indirect impacts requires statistical power and control of potential confounding factors [20,95].

To ensure that the studies achieve reliable/meaningful results, some critical aspects should be considered.

\subsubsection{Robust Experimental Design and Sampling Effort}

Before-after control-impact (BACI) and before-after gradient (BAG or BAG-C) designs are considered the most robust approaches to evaluate environmental impacts and, as with any experiment, they become more powerful when more replicates are used $[95,96]$. Multi-year and multi-site data collection is therefore recommended (e.g., monitoring of, at least, 3 post-construction years; selection of more than one control site; robust sampling effort within each distance band). Although not always easy to accommodate in a project's development time frame, it is important to ensure that pre-construction baseline surveys cover a full year-cycle (ideally more) and that any construction activities are still not taking place. 


\subsubsection{Definition of Study Area Limits and Appropriate Distance Bands}

Displacement effects may occur at different spatial scales depending on the taxonomic group or even within the same taxon. It is, therefore, important to guarantee that the limits of the survey area, and the size of the distance bands, are appropriate for detecting effects on the target species. For instance, if the wind farm area is too large (e.g., a $500 \mathrm{~m}$ buffer around the turbines), a study may fail to detect displacement effects occurring at a smaller scale (e.g., small passerines), even if a BACI is implemented. If the study considers the most external turbines or the arbitrary private property boundary as the limit of the wind farm area, it might also fail to detect effects in the most immediate area. Similarly, in gradient designs, if the distance bands are too wide (for small home-range species) or, conversely, are too narrow and the last band is located too close to the wind farm (e.g., at a 400-500 m distance, in a study targeting a species with large home-ranges), the study may fail to identify the displacement threshold, i.e., the maximum response distance $[20,97]$.

\subsubsection{Control for Confounding Factors}

Study results can be easily confounded by variation in habitat suitability (between the wind farm area and controls, or along the impact gradient) and by the effects of other anthropogenic landscape elements, such as roads and power lines $[98,99]$. Such potential confounding factors should be addressed primarily through the experimental design, namely through a careful selection of the control areas (that must be as similar as possible to the wind farm site) and the collection of data prior and after the project development. Nonetheless, environmental data should also be collected (e.g., habitat use, vegetation height, distance to other infrastructures) and included as covariates in the statistical models (concurrently with turbine predictors), so wind farm effects may be adequately discerned.

\subsubsection{Selection of the Appropriate Survey Methods/Technologies}

The field methods should be suited for the study target species, population, phenological season and study timeframe and allow the collection of sufficient data to depict changes in bird abundance or spatial-temporal usage. They may include traditional observation techniques (e.g., point/transect counts, vantage points, boat-based or aerial surveys) but also hi-tech methods such as the tagging of individual birds and the radar. The latter can provide valuable information on bird distribution over large areas, although its usefulness for assessing displacement effects depends greatly on the collection of good quality preconstruction data and statistical control of confounders (i.e., landscape variables other than wind turbines) in the data analysis.

\subsection{Reporting and Result Dissemination}

Comprehensive reporting of study methods and results is essential to increase the impact of each individual study and its contribution to the current state of knowledge, namely by enabling its inclusion in systematic reviews and meta-analysis [100]. Some important reporting standards to take into consideration are:

(1) Detailed description of field methods and sampling design, survey effort (e.g., number of sampling sites and replicates; no. of telemetry days) and study area characteristics and limits (e.g., wind farm area and distance to control areas). In BACI and CI designs, it is highly important that the wind farm area considered for the purpose of the study (e.g., area within a $300 \mathrm{~m}$ buffer of the turbines) is clearly defined and reported;

(2) Identification of the statistical approach/criteria used to determine the existence (or not) of significant effects and response distance thresholds [20,101];

(3) Reporting of all outcomes (regardless of the direction or significance) separately for all combinations of factors (e.g., target species or groups, years, seasons) considered in the study;

(4) Identification of the units and measure of variation (SE, SD, 95\% CI, etc.) when reporting values of bird abundance or other parameters of interest; 
(5) In gradient study designs, as much as possible, estimate the maximum influence distance, rather than simply reporting the significance of the variable 'distance to turbine' effect on abundance or space use. The estimate of distance-based threshold responses to wind farms is very important to better understand displacement impacts but also to guide policy and EIA decisions, such as the establishment of protected areas and management actions for species of concern [102].

The utility of the studies conducted ultimately depends on how study findings are disseminated. Study publication in international academic journals is important to overcome language barriers and ensure that study findings are not disseminated without prior expert review [103]. Still, publication bias towards studies that found statistically significant effects, or achieved novel findings, is expected [104]. The publication of studies that achieved non-significant results must continue to be encouraged not only to increase the overall knowledge on the topic but also to prevent redundancy among research studies. Along with academic publishing, study findings should be actively shared with wind farm developers, environmental authorities, non-governmental organizations and other stakeholders to promote evidence-based decisions on future wind energy projects.

\section{Study Limitations}

The results of this review enclose geographical and taxonomical biases that are directly correlated to the locations where studies were or could be developed. Therefore, a higher number of studies was expected from regions with large scale wind industry development and where it has been implemented for a longer time. Even so, bias towards countries with stronger environmental policies that impose monitoring studies, particularly to species of conservation concern or high sensitivity areas is also expected.

Additionally, this systematic review encloses some limitations that should be taken into consideration when analysing the results. First, we focused on peer-reviewed literature and have not considered grey literature. As many studies on interactions between wildlife and infrastructures are conducted in impact assessment frameworks and only a few are eventually published, we have probably missed monitoring studies about the topic. However, even if we had aimed at grey literature, still, many studies would probably not be included, as a large part of grey literature is not publicly or easily accessible, being frequently kept as internal reports and not available online. Moreover, the fact that we only considered studies published in English may have also contributed to missing literature on bird displacement by wind turbines where it has been published in other languages. Although we acknowledge that we were not able to include every piece of information about the topic in this review, the fact that most studies included come from Europe and the United States, where the wind industry has been implemented for a longer time and in large figures, makes us confident that the geographical and taxonomical biases found in this review are a proxy to the real bias and are not due to methodological issues.

\section{Conclusions}

In this review, we have characterized and synthesized the available knowledge on birds' displacement due to wind turbines. The negative effects of wind farms on bird abundance and space use are frequently reported in the literature, affecting species from different habitats, guilds and phylogeny. However, a large number of studies found no effects or even attraction effects, to a smaller extent, even within the same taxa (Table 1). The lack of consistency and clear patterns regarding the effects across and within birds' groups suggests that displacement is probably a species-specific issue and dependent on birds' age and life-cycle, as well as local features and on the wind farm characteristics $[3,5]$, similarly to what happens with birds' collisions with wind turbines [3,4]. Still, the wide variability of methodological protocols applied in the studies may also explain the wide variability of the results.

Research on birds' displacement is fairly recent and it is steadily increasing. However, we detected geographical, taxa and temporal biases. This research topic is still overlooked 
in regions where the wind industry is already implemented, such as South America, Asia and some parts of Africa, namely South Africa. Still, a small number of bird groups are the more frequently targeted by researchers (Accipitriformes, Galliformes, Charadriiformes, Anseriformes and Passeriformes), particularly during the breeding period. Sensible lifecycle periods as migration are still understudied.

In terms of the design of future research, we believe long-term studies are crucial, as only $14 \%$ of the studies sampled 10 or more years after the beginning of operation. It is possible that disturbance caused by wind farms, or attraction effects, are temporary, as continuous exposure over time may increase tolerance or reduce risk perception, causing habituation to the infrastructure [5]. Furthermore, we consider that a better understanding of this topic may be achieved with an investment in the quality of the experimental design of future studies. Robust experimental designs are still a minority among the literature and relevant data is frequently missing, such as a description of the wind farm characteristics or the quantification/extent of the displacement effect.

Future studies will improve our knowledge on the topic and will be essential to guide wind energy development on a large scale, but also at a project level. To date, mitigation measures aiming at bird displacement include avoiding areas with sensitive species to this effect and the implementation of compensatory programs that include habitat management actions [102].

Supplementary Materials: The following are available online at https:/ /www.mdpi.com/article/10 $.3390 /$ birds2040034/s1, Table S1: List of studies focusing on bird displacement with wind turbines compiled through the systematic literature search, and their major characteristics.

Author Contributions: Conceptualization, A.T.M.; methodology, A.T.M. and J.B.; formal analysis, A.T.M.; investigation, H.B. and J.B.; writing —original draft preparation, A.T.M. and J.B.; writingreview and editing, all authors. All authors have read and agreed to the published version of the manuscript.

Funding: This research received no external funding.

Institutional Review Board Statement: Not applicable.

Informed Consent Statement: Not applicable.

Data Availability Statement: The data in this study are available as Supplementary Material. Additional data can be received by the request from the authors.

Acknowledgments: We are thankful to all the colleagues with whom we have worked on interactions between birds and infrastructures along the years. Though too numerous to name, this work would not have been possible without their insights and fruitful collaborations. We also acknowledge the three anonymous reviewers and editor for their comments, which greatly improved the manuscript.

Conflicts of Interest: The authors declare no conflict of interest. 


\section{Appendix A}

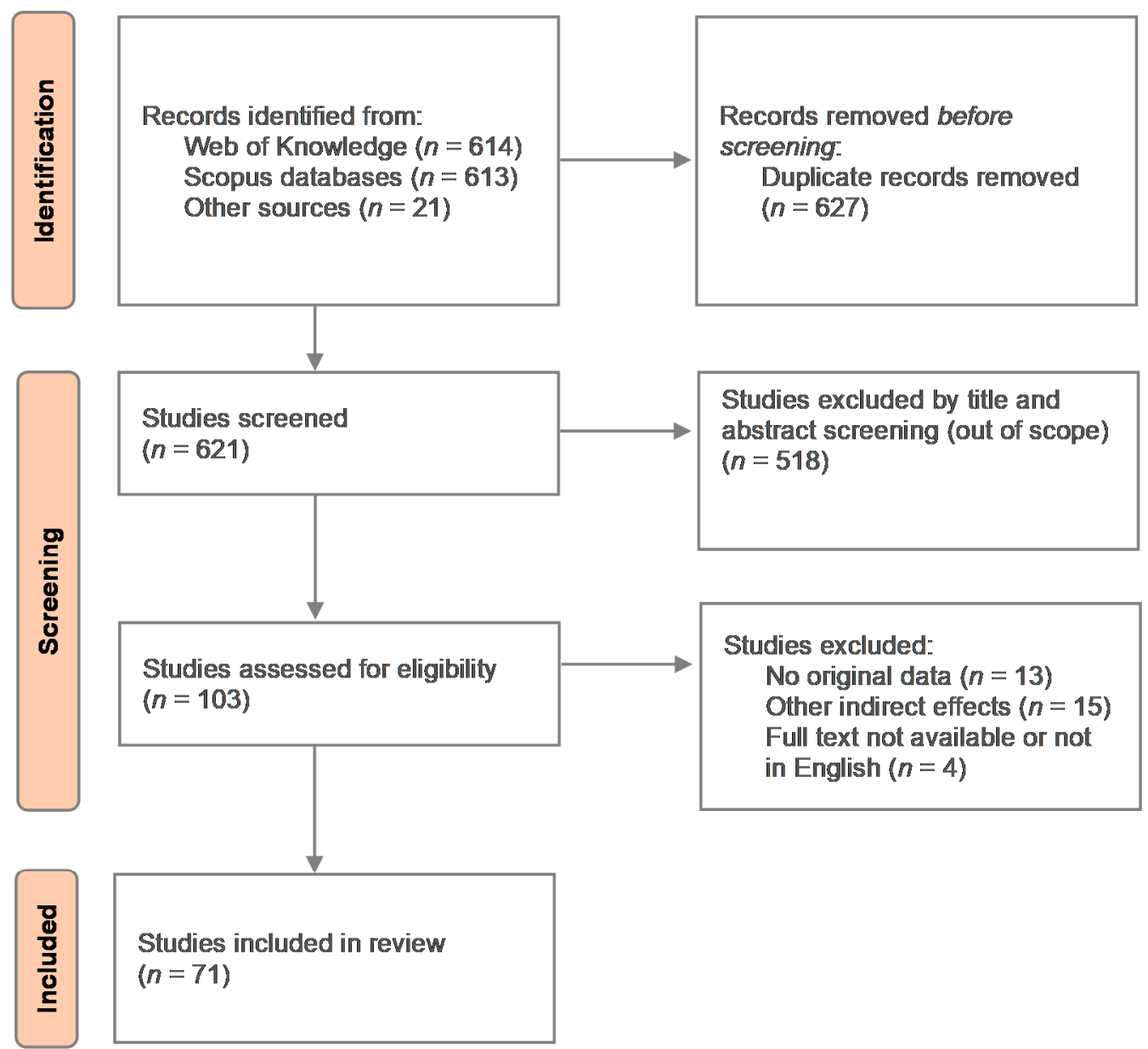

Figure A1. PRISMA flow chart of literature search and selection process.

\section{References}

1. Katzner, T.E.; Nelson, D.M.; Diffendorfer, J.E.; Duerr, A.E.; Campbell, C.J.; Leslie, D.; Vander Zanden, H.B.; Yee, J.L.; Sur, M.; Huso, M.M.P.; et al. Wind energy: An ecological challenge. Science 2019, 366, 1206-1207. [CrossRef]

2. Drewitt, A.L.; Langston, R.H.W. Collision Effects of Wind-power Generators and Other Obstacles on Birds. Ann. N. Y. Acad. Sci. 2008, 1134, 233-266. [CrossRef]

3. Drewitt, A.L.; Langston, R.H.W. Assessing the impacts of wind farms on birds. Ibis 2006, 148, 29-42. [CrossRef]

4. Marques, A.T.; Batalha, H.; Rodrigues, S.; Costa, H.; Pereira, M.J.R.; Fonseca, C.; Mascarenhas, M.; Bernardino, J. Understanding bird collisions at wind farms: An updated review on the causes and possible mitigation strategies. Biol. Conserv. 2014, 179, 40-52. [CrossRef]

5. May, R.F. A unifying framework for the underlying mechanisms of avian avoidance of wind turbines. Biol. Conserv. 2015, 190, 179-187. [CrossRef]

6. Wilson, M.W.; Ridlon, A.D.; Gaynor, K.M.; Gaines, S.D.; Stier, A.C.; Halpern, B.S. Ecological impacts of human-induced animal behaviour change. Ecol. Lett. 2020, 23, 1522-1536. [CrossRef]

7. Thaker, M.; Zambre, A.; Bhosale, H. Wind farms have cascading impacts on ecosystems across trophic levels. Nat. Ecol. Evol. 2018, 2, 1854-1858. [CrossRef]

8. Dierschke, V.; Furness, R.W.; Garthe, S. Seabirds and offshore wind farms in European waters: Avoidance and attraction. Biol. Conserv. 2016, 202, 59-68. [CrossRef]

9. Percival, S. Birds and windfarms. Br. Birds 2005, 98, 194-204.

10. Stewart, G.B.; Pullin, A.S.; Coles, C.F. Poor evidence-base for assessment of windfarm impacts on birds. Environ. Conserv. 2007, 34, 1-11. [CrossRef]

11. Coppes, J.; Braunisch, V.; Bollmann, K.; Storch, I.; Mollet, P.; Grünschachner-Berger, V.; Taubmann, J.; Suchant, R.; Nopp-Mayr, U. The impact of wind energy facilities on grouse: A systematic review. J. Ornithol. 2020, 161, 1-15. [CrossRef]

12. Rees, E.C. Impacts of wind farms on swans and geese: A review. Wildfowl 2012, 62, 37-72. 
13. Pruett, C.L.; PattenN, M.A.; Wolfe, D.H. Avoidance Behavior by Prairie Grouse: Implications for Development of Wind Energy. Conserv. Biol. 2009, 23, 1253-1259. [CrossRef]

14. Schöll, E.M.; Nopp-Mayr, U. Impact of wind power plants on mammalian and avian wildlife species in shrub- and woodlands. Biol. Conserv. 2021, 256, 109037. [CrossRef]

15. Madders, M.; Whitfield, D.P. Upland raptors and the assessment of wind farm impacts. Ibis 2006, 148, 43-56. [CrossRef]

16. Vanermen, N.; Stienen, E. Seabirds: Displacement. In Wildlife and Wind Farms, Conflicts and Solutions. Volume 3. Offshore: Potential Effects; Perrow, M.R., Ed.; Pelagic: Exeter, UK, 2019; pp. 174-205, ISBN 978-1-78427-127-5.

17. Zwart, M.C.; Robson, P.; Rankin, S.; Whittingham, M.J.; McGowan, P.J.K. Using environmental impact assessment and postconstruction monitoring data to inform wind energy developments. Ecosphere 2015, 6, art26. [CrossRef]

18. Hötker, H. Birds: Displacement. In Wildlife and Wind Farms: Conflicts and Solutions. Volume 1. Onshore: Potential Effects; Perrow, M., Ed.; Pelagic: Exeter, UK, 2017; pp. 119-154.

19. Page, M.J.; Moher, D.; Bossuyt, P.M.; Boutron, I.; Hoffmann, T.C.; Mulrow, C.D.; Shamseer, L.; Tetzlaff, J.M.; Akl, E.A.; Brennan, S.E.; et al. PRISMA 2020 explanation and elaboration: Updated guidance and exemplars for reporting systematic reviews. BMJ 2021, 372, n160. [CrossRef]

20. Powell, L.A.; Brown, M.B.; Smith, J.A.; Harrison, J.O.; Whalen, C.E. Modeling the spatial effects of disturbance: A constructive critique to provide evidence of ecological thresholds. Wildlife Biol. 2017, wlb.00245. [CrossRef]

21. Gill, F.; Donsker, D.; Rasmussen, P. IOC World Bird List (v11.2); 2021. Available online: https://www.worldbirdnames.org/new/ (accessed on 1 November 2021). [CrossRef]

22. IRENA Renewable Energy Statistics 2020; International Renewable Energy Agency: Abu Dhabi, United Arab Emirates, 2021.

23. Morgan, R.K. Environmental impact assessment: The state of the art. Impact Assess. Proj. Apprais. 2012, 30, 5-14. [CrossRef]

24. Larsen, J.K.; Madsen, J. Effects of wind turbines and other physical elements on field utilization by pink-footed geese (Anser brachyrhynchus): A landscape perspective. Landsc. Ecol. 2000, 15, 755-764. [CrossRef]

25. Farfán, M.A.; Vargas, J.M.; Duarte, J.; Real, R. What is the impact of wind farms on birds? A case study in southern Spain. Biodivers. Conserv. 2009, 18, 3743-3758. [CrossRef]

26. Santos, C.D.; Ferraz, R.; Muñoz, A.-R.; Onrubia, A.; Wikelski, M. Black kites of different age and sex show similar avoidance responses to wind turbines during migration. R. Soc. Open Sci. 2021, 8, 201933. [CrossRef]

27. Skov, H.; Desholm, M.; Heinänen, S.; Kahlert, J.A.; Laubek, B.; Jensen, N.E.; Žydelis, R.; Jensen, B.P. Patterns of migrating soaring migrants indicate attraction to marine wind farms. Biol. Lett. 2016, 12, 20160804. [CrossRef] [PubMed]

28. Dohm, R.; Jennelle, C.S.; Garvin, J.C.; Drake, D. A long-term assessment of raptor displacement at a wind farm. Front. Ecol. Environ. 2019, 17, 433-438. [CrossRef]

29. Farfán, M.A.; Duarte, J.; Real, R.; Muñoz, A.R.; Fa, J.E.; Vargas, J.M. Differential recovery of habitat use by birds after wind farm installation: A multi-year comparison. Environ. Impact Assess. Rev. 2017, 64, 8-15. [CrossRef]

30. Keehn, J.E.; Feldman, C.R. Disturbance affects biotic community composition at desert wind farms. Wildl. Res. 2018, 45, 383. [CrossRef]

31. Pearce-Higgins, J.W.; Stephen, L.; Langston, R.H.W.; Bainbridge, I.P.; Bullman, R. The distribution of breeding birds around upland wind farms. J. Appl. Ecol. 2009, 46, 1323-1331. [CrossRef]

32. May, R.; Nygård, T.; Dahl, E.L.; Bevanger, K. Habitat utilization in white-tailed eagles (Haliaeetus albicilla) and the displacement impact of the Smøla wind-power plant. Wildl. Soc. Bull. 2013, 37, 75-83. [CrossRef]

33. Campedelli, T.; Londi, G.; Cutini, S.; Sorace, A.; Tellini Florenzano, G. Raptor displacement due to the construction of a wind farm: Preliminary results after the first 2 years since the construction. Ethol. Ecol. Evol. 2014, 26, 376-391. [CrossRef]

34. Garvin, J.C.; Jennelle, C.S.; Drake, D.; Grodsky, S.M. Response of raptors to a windfarm. J. Appl. Ecol. 2011, 48, 199-209. [CrossRef]

35. Marques, A.T.; Santos, C.D.; Hanssen, F.; Muñoz, A.; Onrubia, A.; Wikelski, M.; Moreira, F.; Palmeirim, J.M.; Silva, J.P. Wind turbines cause functional habitat loss for migratory soaring birds. J. Anim. Ecol. 2020, 89, 93-103. [CrossRef] [PubMed]

36. Wilson, M.W.; Fernández-Bellon, D.; Irwin, S.; O'Halloran, J. Hen Harrier Circus cyaneus population trends in relation to wind farms. Bird Study 2017, 64, 20-29. [CrossRef]

37. Walker, D.; Mcgrady, M.; Mccluskie, A.; Madders, M.; Mcleod, D.R.A. Resident Golden Eagle ranging behaviour before and after construction of a windfarm in Argyll. Scottish Birds 2005, 25, 24-40.

38. Hull, C.L.; Muir, S.C. Behavior and turbine avoidance rates of eagles at two wind farms in Tasmania, Australia. Wildl. Soc. Bull. 2013, 37, 49-58. [CrossRef]

39. Hernández-Pliego, J.; de Lucas, M.; Muñoz, A.-R.; Ferrer, M. Effects of wind farms on Montagu's harrier (Circus pygargus) in southern Spain. Biol. Conserv. 2015, 191, 452-458. [CrossRef]

40. Balotari-Chiebao, F.; Brommer, J.E.; Niinimäki, T.; Laaksonen, T. Proximity to wind-power plants reduces the breeding success of the white-tailed eagle. Anim. Conserv. 2016, 19, 265-272. [CrossRef]

41. de Lucas, M.; Janss, G.F.E.; Ferrer, M. The effects of a wind farm on birds in a migration point: The Strait of Gibraltar. Biodivers. Conserv. 2004, 13, 395-407. [CrossRef]

42. Madsen, J.; Boertmann, D. Animal behavioral adaptation to changing landscapes: Spring-staging geese habituate to wind farms. Landsc. Ecol. 2008, 23, 1007-1011. [CrossRef]

43. Loesch, C.R.; Walker, J.A.; Reynolds, R.E.; Gleason, J.S.; Niemuth, N.D.; Stephens, S.E.; Erickson, M.A. Effect of wind energy development on breeding duck densities in the Prairie Pothole Region. J. Wildl. Manag. 2013, 77, 587-598. [CrossRef] 
44. Larsen, J.K.; Guillemette, M. Effects of wind turbines on flight behaviour of wintering common eiders: Implications for habitat use and collision risk. J. Appl. Ecol. 2007, 44, 516-522. [CrossRef]

45. Fijn, R.C.; Krijgsveld, K.L.; Tijsen, W.; Prinsen, H.A.; Dirksen, S. Habitat use, disturbance and collision risks for Bewick. Wildfowl 2012, 62, 97-116.

46. Desholm, M.; Kahlert, J. Avian collision risk at an offshore wind farm. Biol. Lett. 2005, 1, 296-298. [CrossRef]

47. Plonczkier, P.; Simms, I.C. Radar monitoring of migrating pink-footed geese: Behavioural responses to offshore wind farm development. J. Appl. Ecol. 2012, 49, 1187-1194. [CrossRef]

48. Zehtindjiev, P.; Vasilev, V.; Marinov, M.P.; Ilieva, M.; Dimitrov, D.; Peev, S.; Raykov, I.; Raykova, V.; Ivanova, K.; Bedev, K.; et al. No Evidence for Displacement of Wintering Red-breasted Geese Branta ruficollis (Pallas, 1769)(Anseriformes) at a Wind Farms Area in Northeast Bulgaria: Long-term Monitoring Results. Acta Zool. Bulg. 2017, 69, 215-228.

49. Meek, E.R.; Ribbands, J.B.; Christer, W.G.; Davy, P.R.; Higginson, I. The effects of aero-generators on moorland bird populations in the Orkney Islands, Scotland. Bird Study 1993, 40, 140-143. [CrossRef]

50. Rothery, P.; Newton, I.; Little, B. Observations of seabirds at offshore wind turbines near Blyth in northeast England. Bird Study 2009, 56, 1-14. [CrossRef]

51. Lange, C.J.; Ballard, B.M.; Collins, D.P. Impacts of wind turbines on redheads in the Laguna Madre. J. Wildl. Manag. 2018, 82, 531-537. [CrossRef]

52. Welcker, J.; Nehls, G. Displacement of seabirds by an offshore wind farm in the North Sea. Mar. Ecol. Prog. Ser. 2016, 554, 173-182. [CrossRef]

53. Shaffer, J.A.; Buhl, D.A. Effects of wind-energy facilities on breeding grassland bird distributions. Conserv. Biol. 2016, 30, 59-71. [CrossRef]

54. Vanermen, N.; Onkelinx, T.; Courtens, W.; Van de walle, M.; Verstraete, H.; Stienen, E.W.M. Seabird avoidance and attraction at an offshore wind farm in the Belgian part of the North Sea. Hydrobiologia 2015, 756, 51-61. [CrossRef]

55. Pearce-Higgins, J.W.; Stephen, L.; Douse, A.; Langston, R.H.W. Greater impacts of wind farms on bird populations during construction than subsequent operation: Results of a multi-site and multi-species analysis. J. Appl. Ecol. 2012, 49, 386-394. [CrossRef]

56. Sansom, A.; Pearce-Higgins, J.W.; Douglas, D.J.T. Negative impact of wind energy development on a breeding shorebird assessed with a BACI study design. Ibis 2016, 158, 541-555. [CrossRef]

57. Vanermen, N.; Courtens, W.; Daelemans, R.; Lens, L.; Müller, W.; Van de walle, M.; Verstraete, H.; Stienen, E.W.M. Attracted to the outside: A meso-scale response pattern of lesser black-backed gulls at an offshore wind farm revealed by GPS telemetry. ICES J. Mar. Sci. 2020, 77, 701-710. [CrossRef]

58. Peschko, V.; Mercker, M.; Garthe, S. Telemetry reveals strong effects of offshore wind farms on behaviour and habitat use of common guillemots (Uria aalge) during the breeding season. Mar. Biol. 2020, 167, 118. [CrossRef]

59. Peschko, V.; Mendel, B.; Müller, S.; Markones, N.; Mercker, M.; Garthe, S. Effects of offshore windfarms on seabird abundance: Strong effects in spring and in the breeding season. Mar. Environ. Res. 2020, 162, 105157. [CrossRef] [PubMed]

60. Douglas, D.J.T.; Bellamy, P.E.; Pearce-Higgins, J.W. Changes in the abundance and distribution of upland breeding birds at an operational wind farm. Bird Study 2011, 58, 37-43. [CrossRef]

61. Niemuth, N.D.; Walker, J.A.; Gleason, J.S.; Loesch, C.R.; Reynolds, R.E.; Stephens, S.E.; Erickson, M.A. Influence of Wind Turbines on Presence of Willet, Marbled Godwit, Wilson's Phalarope and Black Tern on Wetlands in the Prairie Pothole Region of North Dakota and South Dakota. Waterbirds 2013, 36, 263-276. [CrossRef]

62. Vallejo, G.C.; Grellier, K.; Nelson, E.J.; McGregor, R.M.; Canning, S.J.; Caryl, F.M.; McLean, N. Responses of two marine top predators to an offshore wind farm. Ecol. Evol. 2017, 7, 8698-8708. [CrossRef]

63. Bai, M.-L.; Chih, W.-C.; Lee, P.-F.; Lien, Y.-Y. Response of waterbird abundance and flight behavior to a coastal wind farm on the East Asian-Australasian Flyway. Environ. Monit. Assess. 2021, 193, 181. [CrossRef] [PubMed]

64. Battisti, C.; Fortunati, L.; Ferri, V.; Dallari, D.; Lucatello, G. Lack of evidence for short-term structural changes in bird assemblages breeding in Mediterranean mosaics moderately perforated by a wind farm. Glob. Ecol. Conserv. 2016, 6, 299-307. [CrossRef]

65. Garcia, D.A.; Canavero, G.; Ardenghi, F.; Zambon, M. Analysis of wind farm effects on the surrounding environment: Assessing population trends of breeding passerines. Renew. Energy 2015, 80, 190-196. [CrossRef]

66. Łopucki, R.; Klich, D.; Gielarek, S. Do terrestrial animals avoid areas close to turbines in functioning wind farms in agricultural landscapes? Environ. Monit. Assess. 2017, 189, 343. [CrossRef] [PubMed]

67. Coppes, J.; Kämmerle, J.-L.; Grünschachner-Berger, V.; Braunisch, V.; Bollmann, K.; Mollet, P.; Suchant, R.; Nopp-Mayr, U. Consistent effects of wind turbines on habitat selection of capercaillie across Europe. Biol. Conserv. 2020, 244, 108529. [CrossRef]

68. Lebeau, C.W.; Beck, J.L.; Johnson, G.D.; Nielson, R.M.; Holloran, M.J.; Gerow, K.G.; McDonald, T.L. Greater sage-grouse male lek counts relative to a wind energy development. Wildl. Soc. Bull. 2017, 41, 17-26. [CrossRef]

69. LeBeau, C.W.; Johnson, G.D.; Holloran, M.J.; Beck, J.L.; Nielson, R.M.; Kauffman, M.E.; Rodemaker, E.J.; McDonald, T.L. Greater sage-grouse habitat selection, survival, and wind energy infrastructure. J. Wildl. Manag. 2017, 81, 690-711. [CrossRef]

70. Zeiler, H.P.; Gruenschachner-Berger, V. Impact of wind power plants on black grouse, Lyrurus tetrix in Alpine regions. Folia Zool. 2009, 58, 173.

71. Devereux, C.L.; Denny, M.J.H.; Whittingham, M.J. Minimal effects of wind turbines on the distribution of wintering farmland birds. J. Appl. Ecol. 2008, 45, 1689-1694. [CrossRef] 
72. González, M.A.; García-Tejero, S.; Wengert, E.; Fuertes, B. Severe decline in Cantabrian Capercaillie Tetrao urogallus cantabricus habitat use after construction of a wind farm. Bird Conserv. Int. 2016, 26, 256-261. [CrossRef]

73. Winder, V.L.; McNew, L.B.; Gregory, A.J.; Hunt, L.M.; Wisely, S.M.; Sandercock, B.K. Space use by female Greater Prairie-Chickens in response to wind energy development. Ecosphere 2014, 5, art3. [CrossRef]

74. Peterson, J.M.; Earl, J.E.; Fuhlendorf, S.D.; Elmore, R.D.; Haukos, D.A.; Tanner, A.M.; Carleton, S.A. Estimating response distances of lesser prairie-chickens to anthropogenic features during long-distance movements. Ecosphere 2020, 11, e03202. [CrossRef]

75. Mcnew, L.B.; Hunt, L.M.; Gregory, A.J.; Wisely, S.M.; Sandercock, B.K. Effects of Wind Energy Development on Nesting Ecology of Greater Prairie-Chickens in Fragmented Grasslands. Conserv. Biol. 2014, 28, 1089-1099. [CrossRef]

76. Winder, V.L.; Gregory, A.J.; McNew, L.B.; Sandercock, B.K. Responses of male Greater Prairie-Chickens to wind energy development. Condor 2015, 117, 284-296. [CrossRef]

77. Harrison, J.O.; Brown, M.B.; Powell, L.A.; Schacht, W.H.; Smith, J.A. Nest site selection and nest survival of Greater PrairieChickens near a wind energy facility. Condor 2017, 119, 659-672. [CrossRef]

78. Mendel, B.; Schwemmer, P.; Peschko, V.; Müller, S.; Schwemmer, H.; Mercker, M.; Garthe, S. Operational offshore wind farms and associated ship traffic cause profound changes in distribution patterns of Loons (Gavia spp.). J. Environ. Manag. 2019, 231, 429-438. [CrossRef] [PubMed]

79. Heinänen, S.; Žydelis, R.; Kleinschmidt, B.; Dorsch, M.; Burger, C.; Morkūnas, J.; Quillfeldt, P.; Nehls, G. Satellite telemetry and digital aerial surveys show strong displacement of red-throated divers (Gavia stellata) from offshore wind farms. Mar. Environ. Res. 2020, 160, 104989. [CrossRef]

80. Pearse, A.T.; Metzger, K.L.; Brandt, D.A.; Shaffer, J.A.; Bidwell, M.T.; Harrell, W. Migrating Whooping Cranes avoid wind-energy infrastructure when selecting stopover habitat. Ecol. Appl. 2021, 31, e02324. [CrossRef]

81. Pearse, A.T.; Brandt, D.A.; Krapu, G.L. Wintering Sandhill Crane exposure to wind energy development in the central and southern Great Plains, USA. Condor 2016, 118, 391-401. [CrossRef]

82. Stevens, T.K.; Hale, A.M.; Karsten, K.B.; Bennett, V.J. An analysis of displacement from wind turbines in a wintering grassland bird community. Biodivers. Conserv. 2013, 22, 1755-1767. [CrossRef]

83. Lemaitre, J.; Lamarre, V. Effects of wind energy production on a threatened species, the Bicknell's Thrush Catharus bicknelli, with and without mitigation. Bird Conserv. Int. 2020, 30, 194-209. [CrossRef]

84. Krecia, L.L.; Higgins, K.F.; Naugle, D.E. Effects of Wind Turbines on Upland Nesting Birds in Conservation Reserve Program Grasslands. Wilson Bull. 1999, 11, 100-104.

85. Gómez-Catasús, J.; Garza, V.; Traba, J. Wind farms affect the occurrence, abundance and population trends of small passerine birds: The case of the Dupont's lark. J. Appl. Ecol. 2018, 55, 2033-2042. [CrossRef]

86. Song, N.; Xu, H.; Zhao, S.; Liu, N.; Zhong, S.; Li, B.; Wang, T. Effects of wind farms on the nest distribution of magpie (Pica pica) in agroforestry systems of Chongming Island, China. Glob. Ecol. Conserv. 2021, 27, e01536. [CrossRef]

87. Hale, A.M.; Hatchett, E.S.; Meyer, J.A.; Bennett, V.J. No evidence of displacement due to wind turbines in breeding grassland songbirds. Condor 2014, 116, 472-482. [CrossRef]

88. de Lucas, M.; Janss, G.F.E.; Ferrer, M. A Bird and Small Mammal BACI and IG Design Studies in a Wind Farm in Malpica (Spain). Biodivers. Conserv. 2005, 14, 3289-3303. [CrossRef]

89. Xu, H.; Zhao, S.; Song, N.; Liu, N.; Zhong, S.; Li, B.; Wang, T. Abundance and behavior of little egrets (Egretta garzetta) near an onshore wind farm in Chongming Dongtan, China. J. Clean. Prod. 2021, 312, 127662. [CrossRef]

90. Peschko, V.; Mendel, B.; Mercker, M.; Dierschke, J.; Garthe, S. Northern gannets (Morus bassanus) are strongly affected by operating offshore wind farms during the breeding season. J. Environ. Manag. 2021, 279, 111509. [CrossRef]

91. Miao, R.; Ghosh, P.N.; Khanna, M.; Wang, W.; Rong, J. Effect of wind turbines on bird abundance: A national scale analysis based on fixed effects models. Energy Policy 2019, 132, 357-366. [CrossRef]

92. Fernández-Bellon, D.; Wilson, M.W.; Irwin, S.; O'Halloran, J. Effects of development of wind energy and associated changes in land use on bird densities in upland areas. Conserv. Biol. 2019, 33, 413-422. [CrossRef]

93. Larsson, A.-K. The Environmental Impact from an Offshore Plant. Wind Eng. 1994, 18, $213-218$.

94. Hill, D.; Hockin, D.; Price, D.; Tucker, G.; Morris, R.; Treweek, J. Bird Disturbance: Improving the Quality and Utility of Disturbance Research. J. Appl. Ecol. 1997, 34, 275. [CrossRef]

95. Christie, A.P.; Amano, T.; Martin, P.A.; Shackelford, G.E.; Simmons, B.I.; Sutherland, W.J. Simple study designs in ecology produce inaccurate estimates of biodiversity responses. J. Appl. Ecol. 2019, 56, 2742-2754. [CrossRef]

96. Smokorowski, K.E.; Randall, R.G. Cautions on using the Before-After-Control-Impact design in environmental effects monitoring programs. FACETS 2017, 2, 212-232. [CrossRef]

97. Santos, C.D.; Marques, A.T.; May, R. Recovery of raptors from displacement by wind farms-A response. Front. Ecol. Environ. 2020, 18, 121-122. [CrossRef]

98. Colman, J.E.; Bergmo, T.; Tsegaye, D.; Flydal, K.; Eftestøl, S.; Lilleeng, M.S.; Moe, S.R. Wildlife response to infrastructure: The problem with confounding factors. Polar Biol. 2017, 40, 477-482. [CrossRef]

99. Walters, K.; Kosciuch, K.; Jones, J. Can the effect of tall structures on birds be isolated from other aspects of development? Wildl. Soc. Bull. 2014, 38, 250-256. [CrossRef]

100. Gerstner, K.; Moreno-Mateos, D.; Gurevitch, J.; Beckmann, M.; Kambach, S.; Jones, H.P.; Seppelt, R. Will your paper be used in a meta-analysis? Make the reach of your research broader and longer lasting. Methods Ecol. Evol. 2017, 8, 777-784. [CrossRef] 
101. McDonald, T.L.; Erickson, W.P.; McDonald, L.L. Analysis of Count Data from Before-after Control-Impact Studies. J. Agric. Biol. Environ. Stat. 2000, 5, 262. [CrossRef]

102. Shaffer, J.A.; Loesch, C.R.; Buhl, D.A. Estimating offsets for avian displacement effects of anthropogenic impacts. Ecol. Appl. 2019, 29, e01983. [CrossRef]

103. Amano, T.; González-Varo, J.P.; Sutherland, W.J. Languages Are Still a Major Barrier to Global Science. PLoS Biol. 2016, 14, e2000933. [CrossRef]

104. Møller, A.P.; Jennions, M.D. Testing and adjusting for publication bias. Trends Ecol. Evol. 2001, 16, 580-586. [CrossRef] 